\title{
Ameliorative Effect of Ascorbic Acid and Hibiscus sabdariffa on Cement Kiln Dust-induced Erythrocyte Osmotic Fragility and Lipid Peroxidation in Wistar Rats
}

\author{
Umosen Angela Jecinta ${ }^{1, ~ *}$, Onyeyili Patrick Azubuike ${ }^{1}$, Adenkola Adeshina Yahaya ${ }^{1}$, \\ Rabo Jude Samani \\ ${ }^{1}$ Department of Veterinary Physiology, Pharmacology and Biochemistry, University of Agriculture, Makurdi, Nigeria \\ ${ }^{2}$ Department of Pathology and Microbiology, University of Agriculture, Makurdi, Nigeria
}

Email address:

angeez119@gmail.com (A. J. Umosen)

${ }^{*}$ Corresponding author

\section{To cite this article:}

Umosen Angela Jecinta, Onyeyili Patrick Azubuike, Adenkola AdeshinaYahaya, Rabo Jude Samani. Ameliorative Effect of Ascorbic Acid and Hibiscus sabdariffa on Cement Kiln Dust-induced Erythrocyte Osmotic Fragility and Lipid Peroxidation in Wistar Rats. Journal of Health and Environmental Research. Vol. 4, No. 1, 2018, pp. 10-15. doi: 10.11648/j.jher.20180401.12

Received: January 9, 2018; Accepted: February 1, 2018; Published: February 26, 2018

\begin{abstract}
The present study evaluated the toxic effects of exposure of cement kiln dust, an environmental toxicant on erythrocyte fragility, lipid peroxidation and the ameliorative effect of ascorbic acid and Hibiscus sabdariffa in wistar rats. Thirty six adult male wistar rats divided into six groups of six rats each were used for the study. Rats in group I, II, III and V were administered distilled water $(2 \mathrm{ml})$, ascorbic acid $(100 \mathrm{mg} / \mathrm{kg})$, cement kiln dust $(250 \mathrm{mg} / \mathrm{kg})$ and Hibiscus sabdariffa $(100 \mathrm{mg} / \mathrm{kg})$ respectively. Rats in group IV and VI were treated with ascorbic acid $(100 \mathrm{mg} / \mathrm{kg})$ and Hibiscus sabdariffa $(100$ $\mathrm{mg} / \mathrm{kg}$ ) respectively 30 minutes before administration of cement kiln dust $(250 \mathrm{mg} / \mathrm{kg})$. The treatments were administered by gavage once daily for 90 days. The animals were sacrificed at the end of the treatment period and blood samples collected were analyzed for erythrocyte osmotic fragility and malondialdehyde concentrations using standard methods. The study recorded a higher $(\mathrm{p}<0.05)$ significant malondialdehyde concentration with values of $3.3 \pm 0.1 \mu \mathrm{mol} / 1$ in group III (cement kiln dust treated group), while the lowest significant $(\mathrm{p}<0.05)$ was obtained in group II (ascorbic acid group) with values of $0.6 \pm 0.1$ $\mu \mathrm{mol} / \mathrm{l}$. However the groups administered ascorbic acid and Hibiscus sabdariffa prior to cement kiln dust had significant $(\mathrm{p}<$ 0.05 ) lower levels when compared with group III (cement kiln dust treated group). There was significant $(\mathrm{p}<0.05)$ increase in erythrocyte osmotic fragility in the cement kiln dust treated group, which decreased in the groups co-administered cement kiln dust and ascorbic acid or Hibiscus sabdariffa. The study concluded that prolonged exposure to cement kiln dust caused an increase in malondialdehyde concentration and high erythrocyte osmotic fragility, thus increased hemolysis probably due to increased lipid peroxidation, and administration of ascorbic acid and Hibiscus sabdariffa ameliorated these alterations.
\end{abstract}

Keywords: Cement kiln Dust, Lipid Peroxidation, Ascorbic Acid, Hibiscus sabdariffa

\section{Introduction}

The cement industry is the building block of a nation's construction industry and life without cement in the $21 \mathrm{st}$ century is inconceivable, as few construction projects can take place without utilizing cement somewhere in the design [1]. However, there is increase concern globally as a result of the environmental pollution caused during cement production. The dust emitted from these cement industries appear to have adverse effects on air, water and land [2]. Cement dust has been reported to contain several heavy metals including lead, chromium, cadmium, nickel, arsenic and zinc [3] which have been shown to be potentially harmful to the biotic and abiotic components of the environment when in concentrations above the regulatory limits. These heavy metals have been implicated in many diseases, including blood and genetic diseases, lung, liver and kidney damage and skin and eye defects [4] [5] [6]. Increased development results in frequent exposure of 
animals and humans to the cement dust. Higher elements levels may be attributed to duration of exposure which is a determining factor in serum elements concentration. However, the continuous exposure via inhalation or ingestion makes even the smallest concentration of such toxic elements a concern to the health of animals, humans and the environment. This is because the effects of exposure to any hazardous substance depend on the route of the exposure, duration of exposure and concentration of substance [7]. The heavy metals generate free radicals, which in turn may induce hepatotoxicity, neurotoxicity, nephrotoxicity and degenerative diseases in humans and animals [8] [9]. These observed effects are related to cement kiln dust which must have been transported by the blood stream to the organs and tissues [10]. The damaging actions of free radicals are known to be quenched by antioxidants [11] [12]by preventing and repairing damages caused by reactive oxygen species (ROS)and reactive nitrogen species (RNS). There is therefore the need to prevent the adverse effects of cement kiln dust exposure. This informed the use of ascorbic acid and Hibiscus sabdariffa as antioxidants. Ascorbic acid is a powerful water-soluble antioxidant that directly scavenges oxygen free radicals with or without enzyme catalysts [13]. Hibiscus sabdariffa is an exogenous antioxidant which is plant based and is said to possess flavonoids [14] which are potent antioxidant principles [15].

The present study was aimed at determining the antioxidant potential of ascorbic acid (vitamin C) and the aqueous extract of Hibiscus sabdariffa in reversing or minimizing the oxidative stress and associated damage induced by cement kiln dust.

\section{Materials and Methods}

\subsection{Animals and Treatments}

Forty six (46) adult male wistar rats weighing between 170 $-200 \mathrm{~g}$ were used for the study. They were housed in cages in the Department of Veterinary Physiology, Pharmacology and Biochemistry, College of Veterinary Medicine, University of Agriculture, Makurdi, Benue State. They were fed with growers mash (Vital feed ${ }^{\circledR}$, Nigeria Limited, Jos) containing $14.5 \%$ crude protein, $7 \%$ fat, $7.2 \%$ crude fibre, $1.2 \%$ mineral and vitamin premix supplement. Clean drinking water was provided ad libitum.

\subsection{Collection and Reconstitution of Cement Kiln Dust}

The cement kiln dust was collected according to the method described by [16] from a dust trap placed $1 \mathrm{~km}$ from the cement industry located on Makurdi - Gboko road in Benue state. The dust-laden water was decanted and the dust particles air dried in a controlled environment which was free from dust and other external interference. The weight of the cement kiln dust collected was $385 \mathrm{~g}$. One (1) gram of cement kiln dust was reconstituted in $10 \mathrm{ml}$ of distilled water to make a $10 \%(100 \mathrm{mg} / \mathrm{ml})$ stock solution.

\subsection{Collection of Hibiscus sabdariffa and Aqueous Extract Preparation}

The dried flowers of the plant Hibiscus sabdariffa were obtained from a commercial seller, and identified by a botanist in the Department of Biological Sciences, University of Agriculture, Makurdi, Benue State and a voucher number 500230 was given.

The flowers were pulverized with the help of a mortar and pestle to fine powder and stored in an air tight container. One hundred (100) grammes of Hibiscus sabdariffa powder was dissolved in $1000 \mathrm{ml}$ of distilled water in a conical flask. The mixture was thoroughly shaken and allowed to stand overnight, and thereafter filtered with whatman filter paper No 1 into a measuring cylinder. The filtrate was then concentrated in a rotary evaporator (Rotavapor R210, Buchi, Switzerland) to produce a dark semi solid extract. The extract was preserved in an air tight bottle and stored in a refrigerator at $4{ }^{\circ} \mathrm{C}$ until required for use [17].

Ten (10) grammes of the extract of Hibiscus sabdariffa flower obtained from aqueous method of extraction was measured and placed in a beaker and $100 \mathrm{ml}$ of distilled water added to prepare $10 \%$ stock solution $(100 \mathrm{mg} / \mathrm{ml})$ that was stored in a refrigerator at $4^{\circ} \mathrm{C}$ until required

\subsection{Chemical Acquisition and Preparation}

Ascorbic acid (Vitamin C, Emzor Pharmaceutical ${ }^{\circledR}$ Industries, Ltd, Lagos, Nigeria) was purchased from a reputable pharmacy and $100 \mathrm{mg}$ was dissolved in $2 \mathrm{ml}$ of distilled water to make a $50 \mathrm{mg} / \mathrm{ml}$ suspension daily before administration.

\subsection{Acute Toxicity Estimation of Cement Kiln Dust and Hibiscus sabdariffa in Wistar Rats}

Ten(10) adult male wistar rats (5 each for cement kiln dust and Hibiscus sabdariffa) with an average weight of $147 \mathrm{~g}$ were used for the determination of acute toxicity adopting the method of [18] as modified by [19] [20] using the up and down procedure.

\subsection{Effect of Hibiscus sabdariffa or Ascorbic acid on the Oxidative Stress and Associated Damage Induced by Cement Kiln Dust}

Thirty six (36) adult wistar rats divided randomly into six (6) groups of six (6) animals each were used. Rats in group I, II, III and V were administered distilled water $(2 \mathrm{ml})$, ascorbic acid $(100 \mathrm{mg} / \mathrm{kg})$, cement kiln dust $(250 \mathrm{mg} / \mathrm{kg})$ and Hibiscus sabdariffa $(100 \mathrm{mg} / \mathrm{kg})$ respectively. Rats in group IV and VI were treated with ascorbic acid $(100 \mathrm{mg} / \mathrm{kg})$ and Hibiscus sabdariffa $(100 \mathrm{mg} / \mathrm{kg})$ respectively 30 minutes before administration of cement kiln dust $(250 \mathrm{mg} / \mathrm{kg})$. All treatments were administered by gavage once daily for 90 days. During the treatment period, rats were observed for clinical signs of toxicity and death. Weekly body weight changes were recorded using a digital weighing balance. At the end of the study period, the rats were sacrificed by 
jugular venesection after light chloroform anaesthesia and blood samples were collected into two test tubes, one with anticoagulant EDTA and the other without. The blood with anticoagulant was used for determination of erythrocyte osmotic fragility (EOF) using the method of [21]. The blood collected without anticoagulant was allowed to clot and centrifuged at $800 \times \mathrm{g}$ for $10 \mathrm{~min}$ to obtain serum samples for the determination of malondialdehyde (MDA)[22] using standard methods. The animals were handled in accordance with international guiding principle for biochemical research involving animals [23].

\subsection{Statistical Analysis}

All data obtained were subjected to statistical analysis using one-way analysis of variance (ANOVA) followed by Tukey's post-hoc multiple comparison test using Graph Pad Prism version 4.00 for Windows (www.graphpadprism.com). They were expressed as mean \pm standard error of mean. Values of $\mathrm{p}<0.05$ were considered significant

\section{Results and Discussion}

The administration of cement kiln dust and Hibiscus sabdariffa to rats orally at the dose of $5000 \mathrm{mg} / \mathrm{kg}$ did not produce death nor delayed toxicity signs. Therefore the median lethal dose $\left(\mathrm{LD}_{50}\right)$ was assumed to be greater than $5000 \mathrm{mg} / \mathrm{kg}$.

There was a significant $(\mathrm{p}<0.05)$ increase in percentage hemolysis in the group dosed with CKD alone at 0.3, 0.5, 0.7 and $0.9 \mathrm{~g} / \mathrm{l}$ sodium chloride concentrations with values of $96.2 \pm 1.7 \%, 9.8 \pm 1.2 \%, 5.7 \pm 1.1 \%$ and $6.1 \pm 1.2 \%$ respectively when compared to the other treated groups. The percentage hemolysis of cement kiln dust treated group alone at these sodium chloride concentrations decreased upon coadministration of cement kiln dust with vitamin $\mathrm{C}$ or Hibiscus sabdariffa (Figure 1).

The serum malondialdehyde concentration in the group treated with cement kiln dust alone $(3.3 \pm 0.1 \mu \mathrm{mol} / \mathrm{l})$ was significantly $(\mathrm{p}<0.01)$ higher when compared to the groups treated with distilled water (control) and the other treatment groups. Administration of vitamin $\mathrm{C}$ or Hibiscus sabdariffa decreased the levels of malondialdehyde concentration when compared to that of the control group. The combinations of vitamin $\mathrm{C}+$ cement kiln dust and Hibiscus sabdariffa + cement kiln dust resulted in significantly $(\mathrm{p}<0.05)$ decreased malondialdehyde concentration when compared to that of cement kiln dust treated rats alone. These observed decreases were significantly $(\mathrm{p}<0.05)$ higher when compared to the value obtained in the control group (Figure 2).

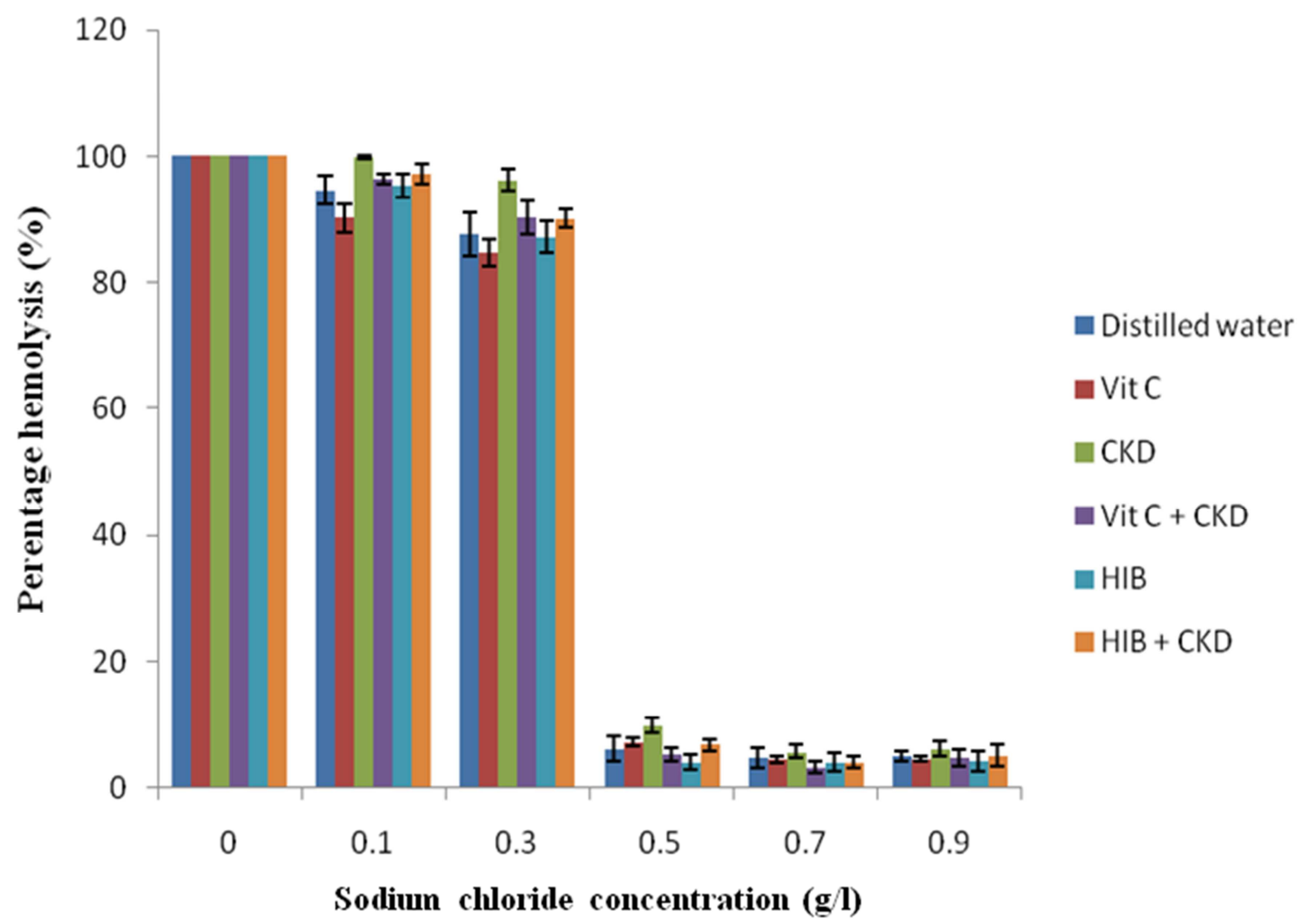

Figure 1. Erythrocyte osmotic fragility variations in wistar rats dosed with cement kiln dust and/or Vitamin C and Hibiscus sabdariffa and their combinations ( $n=7$ observations). 


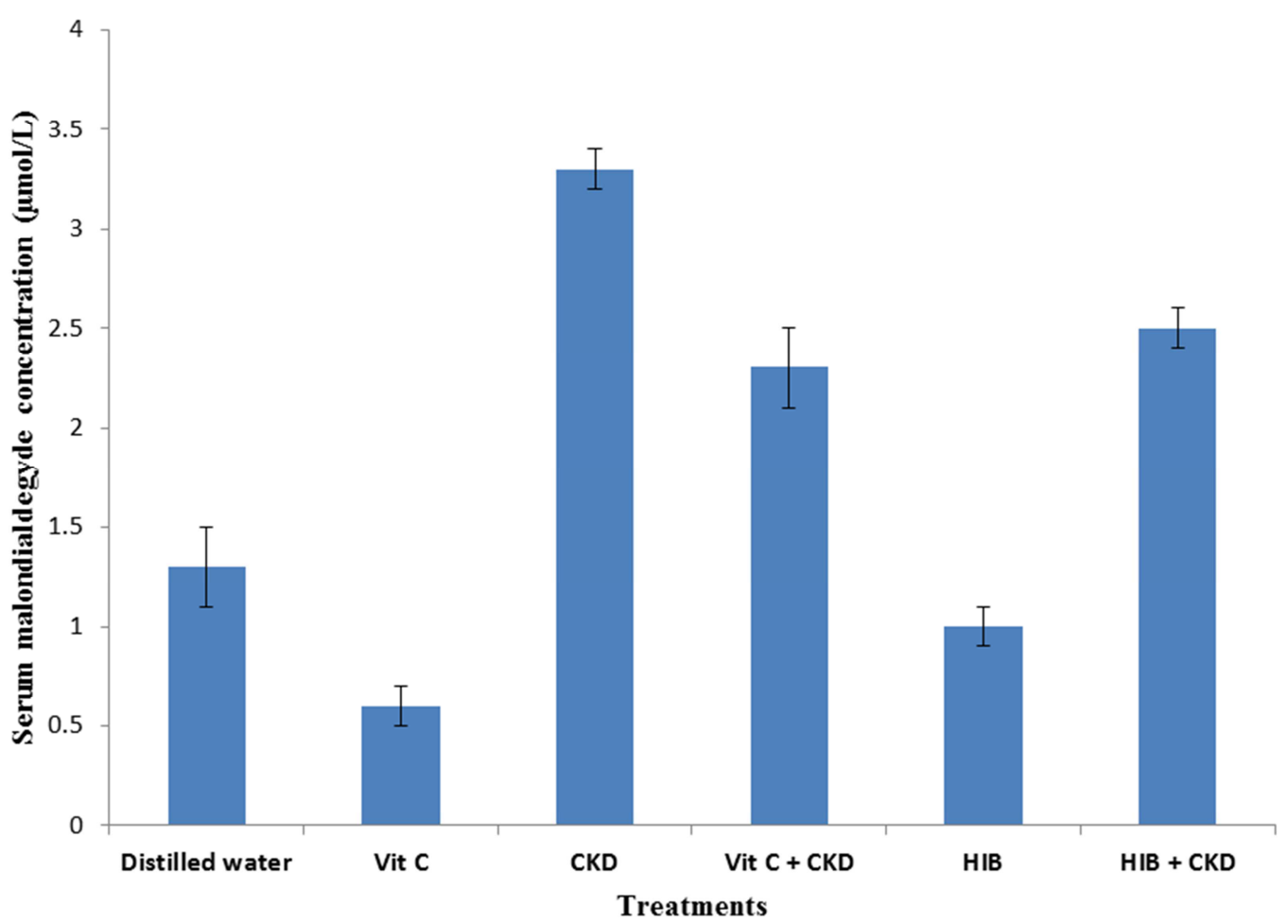

Figure 2. Malondialdehyde concentrations in wistar rats exposed to cement kiln dust alone, and in combination with vitamin $C$ or Hibiscus sabdariffa ( $n=7$ observations).

The acute oral toxicity study of cement kiln dust and Hibiscus sabdariffa at a dose rate of $5000 \mathrm{mg} / \mathrm{kg}$ body weight did not produce mortality or signs of delayed toxicity in the rats. According to [24], substances with per os $\mathrm{LD}_{50}$ of 1000 $\mathrm{mg} / \mathrm{kg}$ body weight are regarded as being safe or of low toxicity. The $\mathrm{LD}_{50}$ of above $5000 \mathrm{mg} / \mathrm{kg}$ obtained in the study with both cement kiln dust and Hibiscus sabdariffa may be an indication that the cement kiln dust and Hibiscus sabdariffa could be administered with a high degree of safety especially through oral route. Absorption of substances might be hindered to some extent due to inherent factors limiting their absorption along the gastrointestinal tract [25].

The present study clearly shows the ability of cement kiln dust to increase lipid peroxidative damage to the erythrocyte, subsequently increasing erythrocyte fragility of the membranes and increase MDA concentration in the cement kiln dust treated rats alone. This is in agreement with earlier studies by [26] [27]which showed that plasma MDA levels were much higher in cement kiln dust - exposed workers when compared to non exposed ones. [28] in their study also observed an increase in MDA concentration in plants on exposure to cement kiln dust which was attributed to increased lipid peroxidation. MDA is a by-product of lipoperoxidation resulting from interaction of oxygen radicals with polyunsaturated fatty acids residues in membrane phospholipids that damage proteins and DNA [29] [30]. The high MDA concentration in the serum of cement kiln dust treated rats in this study is an indication of the level of lipoperoxidative change. Erythrocytes have become a centre of ROS attack due to their high level of iron and polyunsaturated fatty acids [31], as well as their ability to possess nucleus and other organelles coupled with the constant exposure to high oxygen tension [32]. [33] reported that ROS play a vital role in cellular and tissue damage, including those of erythrocytes which are seen as increased hemolysis. Erythrocyte osmotic fragility therefore can be used as an indirect method of evaluating lipid peroxidation in animals since the structural integrity of the erythrocyte membrane is an important feature for its resistance to peroxidative attack [34]. The increased hemolysis observed in the cement kiln dust treated animals in this study may suggest that cement kiln dust exposure brought about the production of ROS which led to lipid peroxidation, hence making the erythrocytes more prone to phagocytosis and lysis.

Although it is evident that organisms have unique systems for protecting themselves against the damaging effects of activated reactive oxygen species (ROS), the need to determine if a boost in the antioxidant status of the rats may reduce oxidative stress became a necessity. This preempted the involvement of antioxidants; vitamin $\mathrm{C}$ and Hibiscus sabdariffa. Treatment with vitamin $\mathrm{C}$ and Hibiscus sabdariffa prior to cement kiln dust produced a decrease in MDA concentrations when compared to the rats administered cement kiln dust alone. This may indicate that vitamin $\mathrm{C}$ and Hibiscus sabdariffa could have the ability to decrease the toxic effect of cement kiln dust by decreasing the level of lipid peroxidation. Ascorbic acid (vitamin C) is a strong antioxidant which activates the functions of all cells; protects and removes toxic substances from the body and intervenes in the regeneration of damaged tissues[35]. It may have produced the reduction of MDA via these abilities. Hibiscus 
sabdariffa also has been reported to possess cell regeneration ability [36]. This is in agreement with study carried out by [37] who observed that both Hibiscus sabdariffa and ascorbic acid reduced the Ferrous Sulphate-induced oxidative stress. The observed hemolysis on the other hand decreased on coadministration of cement kiln dust with vitamin $\mathrm{C}$ or Hibiscus sabdariffa. This appears to agree with observations by [38] who noticed that the administration of vitamins $C, E$ or $\beta$-carotene decreased the osmotic fragility of zinc deficient rats. [39] in their study also reported that vitamin $\mathrm{C}$ supplementation decreased oxidative damage to erythrocytes. The protection of the integrity of the erythrocyte and the reduction in MDA concentration by vitamin $\mathrm{C}$ and Hibiscus sabdariffa observed in the groups where they were coadministered with cement kiln dust further confirms the role of oxidative stress in the toxic mechanism of erythrocyte damage.

\section{Conclusion}

The present study demonstrated the ability of prolonged exposure to cement kiln dust in rats to increase MDA concentration as well as erythrocyte fragility due to elevated lipid peroxidative changes in the erythrocyte membrane which may increase its vulnerability to lysis. In addition, coadministration of cement kiln dust with ascorbic acid (vitamin C) or Hibiscus sabdariffa ameliorated the cement kiln dustinduced lipid peroxidative changes and subsequently reduced the fragility of the erythrocyte. Although the level of toxicity found in short term exposure may be remedied, long term toxicity which is associated with undesirable health consequences is of concern, hence the need for precautionary measures amongst cement factory workers. The result obtained in the study emphasizes the need for relevant care and protection of the health of people who are directly or indirectly exposed to cement and cement kiln dust.

\section{References}

[1] Ogunbileje, J. O., Akinosun, O. M., Arinola, O. G. and Akinduti, P. A. (2010). Immunoglobulin classes (IgG, IgA, $\operatorname{IgM}$ and $\operatorname{IgE}$ ) and liver function tests in Nigerian cement factory workers. Researcher, 2: 55-58.

[2] Raajasubramanian, D., Sundaramoortha, P., Baskaran, L., SankarGanesh, K., Chidambaram, A. L. A. and Jeganathan, M. (2011). Cement dust pollution on growth yield attribute of groundnut (ArachishypogaeaL.). International Multidisciplinary Research Journal, 1(1):3136.

[3] Yahaya, T. and Okpuzor, J. (2011). Variation in cement dust exposure in relation to distance from cement factory. Research Journal of Environmental Toxicology. 5: 203-212.

[4] Akinola, M. O., Okwok, N. A. and Yahaya, T. (2008). The effects of cement dust on Albino rats (Rattusnorvegicus) around West African Portland cement Factory in Sagamu, Ogun State, Nigeria. Research Journal of Environmental Toxicology, 2 (1): 1-8.
[5] Zeleke, Z., Moen, B. and Bratveit, M. (2010). Cement dust exposure and acute lung function: A cross shift study. $B M C$ Pulmonary Medicine, 10 (1): 19.

[6] Yahaya, T., Okpuzor J. and Adedayo, T. F. (2011). Investigation of general effects of cement dust to clear the controversy surrounding its toxicity. Asian Journal of Scientific Research, 4: 315-325.

[7] Egbe, E. R., Nsonwu-Anyanwu, A. C., Offor, S. J., Usoro, C. A. O., Etukodo, M. H. and Egbe, D. I. (2016). Cement dust exposure and perturbations in some elements and lung and liver functions of cement factory workers. Journal of Toxicology, $7 \mathrm{pp}$.

[8] Stohs, S. J. and Bagchi, D. (1995). Oxidative mechanisms in the toxicity of metal-ions. Free Radical Biology and Medicine, 18: 321-336.

[9] Chen, F., Ding, M., Castranova, V. and Shi, X. L. (2001). Carcinogenic metals and NF-kappa B activation. Molecular and Cell Biochemistry, 222: 159 - 171.

[10] Emmanuel, T. F., Okaka, A. N. C., Ibiam, U. A. and Sanni, M. (2017). The toxicological effect of cement dust on hepatic and renal functions of cement factory workers. International Journal of Life Sciences Research, 5: 37-45.

[11] Akinwade, A. I and Adebule, A. O. A. (2003). Ascorbic acid and Beta-carotene alleviate oxidative effect of London Kingsize ${ }^{\circledR}$ cigarette smoke on tissue lipids. Nigerian Journal of Health and Biomedical Sciences, 2 (1): 12-15.

[12] Adenkola, A. Y., Carew, N. S., Ojabo, L. D. and Angani, M. T. (2016). Comparative Studies Ascorbic Acid and Hibiscus sabdariffa Calyces against Heat-Stress Inclusion in Broiler Chicken. Alexandria Journal of Veterinary Sciences, 51 (1): 17-23.

[13] Sies, H. (1997). Oxidative stress: oxidants and antioxidants. Experimental Physiology, 82: 291-295.

[14] Olusola, A. O. (2011). Evaluation of the antioxidant effects of Hibiscus sabdariffa calyx extracts on 2, 4dinitrophenylhydrazine-induced oxidative damage in rabbit. Webmed Central. Com: Biochemistry. 2 (10).

[15] Ologundudu, A., Ologundudu, A. O., Oluba, O. M., Omotuyi, I. O. and Obi, F. O. (2010). Effect of Hibiscus sabdariffa anthocyanins on 2 4-dinitrophenylhydrazine-induced tissue damage in rabbits. Journal of Toxicology and Environmental Health, Sci 2(1): 1.

[16] McTainsh, G. H. and Walker P. H. (1982). Nature and Distribution of Harmattan dust. Zeitschrift fur Geomorphologie, 26 (4): 417-435.

[17] Ajagbonna, O. P. and A. E. Adebayo. (2001). Safety evaluation of acute and chronic treatment of aqueous calyx extract of Hibiscus sabdariffa L. in rats. Sokoto Journal of Veterinary Science, 3: 20-26.

[18] Dixon, W. J. and Mood, A. M. (1948). A Method for Obtaining and Analyzing Sensitivity Data. Journal of the American Statistical Association, 43: 109-126.

[19] Dixon, W. J. (1965). The up and down method for small samples. Journal of the American Statistiscal Association, 43: 109-136.

[20] Dixon, W. J. (1991). Staircase Bioassay: The up and down method. Neuroscience and Biobehavioural Reviews, 15: 47-50. 
[21] Faulkner, W. R. and King, J. W. (1970). Manual of clinical laboratory procedures. Cleveland Ohio, Chemical Rubber Company. 354 pp.

[22] Draper, H. H. and Hadley, M. (1990). Malondialdehyde determination as index of lipid peroxidation. Methods in Enzymology 186: 421-431.

[23] C. I. O. M. S. (1985). International Guiding Principles for Biochemical Research Involving Animals. Council for International Organisation of Medical Sciences (CIOMS). c/o World Health Organisation, 1211, Geneva 27, Switzerland.

[24] Clarke, E. G. C. and Clarke, M. L. (1977). Veterinary Toxicology. Cassel and Collier Macmillan Publishers, London. Pp 268-277.

[25] Abatan, M. O. and Arowolo, R. O. (1989). Toxicity of Eugenia uniflora to rats. Nigerian Journal of Animal Production, 16: 16-19.

[26] Aydin, S., I. Aral, N. Kilic, I. Bakan, S. Aydin and F. Erman. 2004. The level of antioxidant enzymes, plasma vitamins C and E in cement plant workers. Clinica Chimica Acta 341 (12): $193-198$.

[27] Khaled, S. A. S. (2014). Assessment of oxidative Stress, haematological, kidney and liver function parameters of Libyan cement factory workers. Journal of American Science, 10 (5): $58-65$

[28] Abu-Romman, S. and Alzubi, J. (2015). Effects of Cement Dust on the Physiological Activities of Arabidopsis thaliana. American Journal of Agricultural and Biological Sciences, 10 (4): $157-164$.

[29] Krishnamoorthy, G., Ventaraman, P., Arunkumar, A., Vignesh, R. C., Aruldhas, M. M. and Arunakaran, J. (2007). Ameliorative effect of vitamins $(\alpha-$ tocopherol and ascorbic acid) on PCB (Aroclor 1254)-induced oxidative stress in rat epididymal sperm. Toxicology Reports, 23: 239-245.

[30] Umosen, A. J., Ambali, S. F., Ayo, J. O., Mohammed, B and Uchendu, C. (2012). Alleviating effects of melatonin on oxidative changes in the testes and pituitary glands evoked by subacutechlorpyrifos administration in Wistar rats. Asian Pacific Journal of Tropical Biomedicine, 2 (8): 645-650.
[31] Kollanjiappan, K., Manoharan, S. and Kayalvizhi, M. (2002). Measurement of erythrocyte lipids, lipid peroxidation, antioxidants and osmotic fragility in cervical cancer patients. Clinica Chimica Acta, 326: 143-149.

[32] Doroevic, N. Z., Barbic, G. M., Markovic, S. D., Ognjanovic, B. K., Stajn, A. S., Zikic, R. V. and Salcic, Z. S. (2008). Oxidative stress and changes in antioxidative defense system erythrocytes of preeclampsia in women. Reproductive Toxicology, 25: 213-218.

[33] Tkaczyk, J. and Vizek, M. 2007. Oxidative stress in the lung tissue sources of reactive oxygen species and antioxidant defence. Prague Medical Report, 107(2): 105-114.

[34] Chihuailaf, R. H., Conteras, P. A. and Wittwer, F. G. (2002). Pathogenesis of oxidative stress: Consequences and evaluation in animal health. Veterinaria Mexico, 33 (3): 265-283.

[35] Poornima, G. N. and Ravishankar, R. V. (2009). Evaluation of phytonutrients and vitamin contents in a wild yam, Dioscoreabelophylla (Prain) Haines. African Journal of Biotechnology. 8(6): 971-973.

[36] Nayak, B. S., Raju, S. S., Orette, F. A., Rao, A. V. O. (2007). Effects of Hibiscus Rosa sinensisL. on Wound Healing Activity: A Preclinical Study in a Sprague Dawley Rat. International Journal of Low and Extreme Wounds. 6(2): 76-81.

[37] Mowuogwu, F. O. and George, B. O. (2008).]Comparative Antioxidant Activity of Hibiscus sabdariffaand Ascorbic Acid on Ferrous Sulphate-induced Oxidative Stress in Clarias gariepinus. East and Central African Journal of Pharmaceutical Sciences 11: 39-42.

[38] Kraus, A., Roth, H. P. and Kirchgessner, M. (1997). Supplementation with vitamin C, vitamin E or beta-carotene influences osmotic fragility and oxidative damage of erythrocytes of zinc-deficient rats. Journal of Nutrition, (127): 1290-1296.

[39] Devi, S. A., Vani, R., Subramanyam, M. V. V., Reddy, S. S. and Jeevaratnam, K. 2007. Intermittent hypobaric hypoxiainduced oxidative stress in rat erythrocytes: protective effects of vitamin E, vitamin C, and carnitine. Cell Biochemistry and Function, 25: 221-231. 